\title{
Alteration of fatty acid molecular species in ceramide and glucosylceramide under heat stress and expression of sphingolipid-related genes
}

\author{
Ken-ichi Nagai ${ }^{1}$, Nobuyoshi Takahashi ${ }^{2}$, Toshiko Moue ${ }^{3}$, Yukio Niimura ${ }^{3^{*}}$ \\ ${ }^{1}$ Department of Clinical Laboratory Science, Faculty of Medical Technology, Teikyo University, Tokyo, Japan; \\ ${ }^{2}$ Department of Radiological Technology, Faculty of Medical Technology, Teikyo University, Tokyo, Japan; \\ ${ }^{3}$ Research Center of Biomedical Analysis and Radioisotope, Faculty of Medicine, Teikyo University, Tokyo, Japan. \\ Email: ${ }^{*}$ yniimura@med.teikyo-u.ac.jp
}

Received 15 September 2011; revised 21 October 2011; accepted 29 October 2011.

\section{ABSTRACT}

Physical stresses such as high temperature or hyperosmosis are known causes of intracellular ceramide (Cer) accumulation in mammalian epithelial cells; these stresses also result in the activation of the biosyntheses of glucosylceramide (GlcCer) or galactosylceramide via ceramide glycosylation. We confirmed that intracellular Cer and GlcCer increased in mouse fibroblast Mop 8 cells under conditions of heat stress. When molecular species of Cer, GlcCer and sphingomyelin (SM) were analyzed by matrix assisted laser desorption ionization time of flight mass spectrometry (MALDI-TOF MS), the molecular ion peaks of Cer (d18:1 - C16:0, $\mathrm{Na}^{+}$) and Cer (d18:1 - C22:0, $\mathrm{Na}^{+}$) increased under heat stress compared with those of Cer (d18:1 - C24:1, $\mathrm{Na}^{+}$) and Cer (d18:1 - C24:0, $\mathrm{Na}^{+}$). GlcCer and SM demonstrated the wide spectra of fatty acyl chains compared with that of Cer. The ratio of GlcCer consisted of hydroxy fatty acid to that consisted of non-hydroxy fatty acid increased 2-5-fold in heat stressed cells. Cer metabolism-related genes, serine palmitoyltransferase (Spt), ceramide synthase-1, $-2,-4,-5$ and -6 (CerS1, $-2,-4,-5$ and -6 ), neutral sphingomyelinase-1 and -2 (nSMase1 and nS-Mase2), sphingomyelin synthase-1 (SgmS1), and ceramide glucosyltransferase (GICT), were activated after $16 \mathrm{~h}$ under heat stress at $42^{\circ} \mathrm{C}$. Activation of Sg-mS1 and GICT genes played a role as Cer scavengers in the decrease of intracellular Cer levels. Activation of CerS5 and/or CerS6 gene may contribute to the accumulation of Cer species of (d18:1 - C16:0) under heat stress.

Keywords: Ceramide; Glucosylceramide; Heat Stress; Fatty Acids; Ceramide Synthases

\section{INTRODUCTION}

Ceramide (Cer) plays the role of a lipid second messenger in cell signaling transductions [1-5] such as cell growth, differentiation [6], senescence [7], necrosis [8], proliferation [9], and apoptosis [10]. Changes in Cer metabolism are also implicated in the etiology of human diseases, such as neurological disorders, cancer, infectious diseases, and Wilson's disease [11,12]. The accumulation of Cer in response to heat-shock stress has been shown in HL-60 [13,14] and NIH WT-3T3 cells [15] and is dependent on the activities of both serine palmitoyltransferase (Spt) and ceramide synthase (CerS) [16]. The generation of Cer may result from de novo synthesis and/or sphingomyeline (SM) degradation by acid sphingomyelinase (aSMase) or neutral sphingomyelinase (nSMase). The nSMase which hydrolyzes SM to generate Cer plays a critical role in stress responses including apoptosis [17]. Cer is an important initial precursor in sphingoglycolipid metabolism. Cer glycosylation is involved in the regulation of Cer content in B16 melanoma cells [18], and glucosylceramide (GlcCer) synthesis protects against Cer-induced stress in keratinocytes [19]. In previous studies we demonstrated that hyperosmotic stress to Madin-Darby canine kidney (MDCK) cells increased Cer content, and the mRNA level of Cer galactosyltransferase (GalT) was upregulated resulting in galactosylceramide (GalCer) accumulation [20]. Hyperosmotic stress also affected the syntheses of more complex glycosphingolipids such as sulfoglycolipids by the mitogen-activated protein kinase (MAPK) signaling pathway [21]. In our recent study [22], heat-stressed MDCK cells had an increased content of Cer, and the de novo synthesis from serine and both GlcCer and GalCer syntheses from Cer were shown to increase by metabolic labeling. The gene expression of Cer glucosyltransferase (GlcT) and GalT also increased significantly under heat stress. 
In this study we examined Cer levels, molecular species of Cer, GlcCer and SM, and expression of sphingolipid-related genes in mouse fibroblasts subjected to heat stress.

\section{MATERIALS AND METHODS}

\subsection{Reagents and Standards}

Protein concentrations were determined with Quick Start Bradford Dye Reagent (Bio-Rad, Hercules, CA, USA). GlcCer and lactosylceramide (LacCer) were prepared in our laboratory from horse kidney and human kidney, respectively. GalCer from bovine brain, phosphatidyl se-rine (PS), phosphatidyl choline (PC), phosphatidyl ethanolamine (PE) and SM were obtained from SigmaAldrich Co. (St. Louis, MO, USA). Cer from bovine brain was purchased from Funakoshi Co. (Tokyo, Japan). Thin layer chromatography (TLC) was performed on Silica gel 60 high-performance TLC (HPTLC) plates (Merck, Darmstadt, Germany). Orcinol reagent was used for detection of glycolipids and primuline reagent was used for detection of lipids.

\subsection{Cell Culture}

Mop-8 cells [23] with a hybrid transcription unit composed of the SV40 early promoter fused to the early region of Polyoma virus were purchased from American Type Culture Collection (ATCC) and cultured in Dulbecco's modified Eagle's medium (D-MEM, Nissui Pharmaceutical Co., Tokyo, Japan) containing 10\% fetal bovine serum (FBS) (Invitrogen, Carlsbad, CA, USA). Heat stress was introduced at $40^{\circ} \mathrm{C}$ or $42^{\circ} \mathrm{C}$.

\subsection{Metabolic Labeling of Cer and Glycolipids}

${ }^{14} \mathrm{C}(\mathrm{U})$-L-serine $(24.7 \mathrm{kBq} / \mathrm{ml}$; Moravek Biochemicals Inc., Brea, CA, USA) was incorporated into Cer for $16 \mathrm{~h}$ under various conditions. Lipids were extracted and then partitioned with a Folch solvent system containing $0.88 \%$ potassium chloride. An aliquot of the lower phase was analyzed by TLC using stepwise development with two solvents: the first was with chloroform/methanol/acetic acid $(9: 1: 1, \mathrm{v} / \mathrm{v})$ up to the top of the plate, and the second was with chloroform/methanol/ammonia (65:35:7.5, v/v) up to $60 \%$ of the top of the plate. Following TLC, an imaging analyzer (FLA-7000, Fujifilm, Tokyo, Japan) was used to determine radioactivity incorporated into the lipids. Cer, PE, PS, PC, and SM used as standards for TLC were detected by spraying the primuline reagent. Labeling with $\left[1-{ }^{14} \mathrm{C}\right]-\mathrm{D}$-galactose (Moravek Biochemicals Inc.) was performed under the directed conditions. Cells were cultured for $5 \mathrm{~h}$ with ${ }^{14} \mathrm{C}$-galactose $(37 \mathrm{kBq} /$ $\mathrm{ml}$ ), after which lipids were extracted twice with chloroform/methanol $(2: 1$ and $1: 2, \mathrm{v} / \mathrm{v})$. Cells were then treated with alkaline methanol. After neutralization and desalting, the neutral glycolipid fraction was obtained using a DEAE-Sephadex ${ }^{\circledR}$ A-25 (Pharmacia Fine Chemicals AB, Uppsala, Sweden) column. Neutral glycolipids were two-dimensionally (2D) developed on HPTLC plates using chloroform/methanol/water $(60: 25: 4, \mathrm{v} / \mathrm{v})$ and 2-propanol/ammonium hydroxide/methylacetate/water $(15: 2: 1: 3, \mathrm{v} / \mathrm{v})$ [20-22,24]. Total radioactivity incorporated into the glycolipids was measured using a liquid scintillation counter (Packard Instrument Co. Inc., Downers Grove, IL, USA).

\subsection{Preparation of Glycolipids and TLC Analysis}

Non-radioactive glycolipids were also prepared from cells by chloroform/methanol extraction, mild alkali treatment, DEAE-Sephadex ${ }^{\circledR}$ A-25 column chromatography, and TLC as mentioned previously. The glycolipids on TLC were visualized by spraying the plate with orcinol$\mathrm{H}_{2} \mathrm{SO}_{4}$ reagent and heating for several minutes at $120^{\circ} \mathrm{C}$.

\subsection{Mass Spectrometric Analysis}

Matrix-assisted laser desorption ionization time of flight mass spectrometry (MALDI-TOF MS) for lipid samples was carried out on an AXIMA Performance mass spectrometer (Shimadzu Biotech, Manchester, UK) using 2, 5-dihidroxy benzoic acid (DHB, Bruker Daltonics, Bremen, Germany) saturated with sodium chloride as a matrix. Angiotensin II (Shimadzu GLC Ltd.; $\mathrm{MH}^{+}$of 1046.54), C16 Cer (Funakoshi; $\mathrm{MH}^{+}$of 537.90) and $\alpha-$ cyano-4-hydroxycinnamic acid (Shimadzu GLC Ltd.; $\mathrm{MH}^{+}$of 190.05) were used for mass calibration. Lipid solution $(0.5 \mu \mathrm{L})$ was mixed with a matrix solution $(0.5$ $\mu \mathrm{L})$ on the surface of a stainless steel MALDI-TOF plate. All spectra were acquired in the positive ion reflectron mode using a mass spectrometer equipped with a nitrogen UV laser (337 nm). All mass spectrometric data were acquired and analyzed using MALDI-MS software. Typically, 4000 laser shots were acquired for each MS spectrum, and spectra were obtained generally at a laser power of 80 in an attempt to maximize resolution and peak intensity, and analyzed using MALDI-MS software. Helium gas was used for high-energy collision-induced dissociation (CID) fragmentation for MS/MS analysis.

\subsection{Quantification of MRNA by Real-Time Polymerase Chain Reaction (PCR)}

Total RNA was isolated from cells using Trizol reagent (Invitrogen), according to the manufacturer's instructtions. A Transcriptor High Fidelity cDNA Synthesis Kit (Roche Diagnostics GmbH, Mannheim, Germany) was used for reverse transcription of mRNA. The product was appropriately diluted with water and used as a template. ProbeFinder (Roche Diagnostics $\mathrm{GmbH}$ ) for mouse 
mRNA was used to design the optimal real-time PCR assay. For the optimal real-time PCR assay of mouse Spt, long chain base subunit 1 (Sptlc1) mRNA, Universal ProbeLibrary probe \#67 (no. 04688660001, Roche Diagnostics) and a primer set (5'-ggtgetggtggagatggt-3' and 5'ggattccttccaaaataagatgg-3') were used. The 68-base pair (bp) amplicon was detected by agarose gel electrophoresis. Additional Universal ProbeLibrary (UPL) probes and primers were used for real-time PCR assays of mouse Sptlc2, CerS1 - CerS6, nSMase1, nSMase2, SgmS1, GlcT and HSP70 mRNAs as listed in Table 1.

The mouse glyceraldehyde-3-phosphate dehydrogenase (Gapdh) gene was used as the UPL reference gene. A PCR mixture $(20 \mu \mathrm{L} /$ well $)$ was prepared on 96-well plates with LightCycler ${ }^{\circledR} 480$ Probe Master Reagent. The reaction was carried out with a LightCycler ${ }^{\circledR} 480$ (Roche Diagnostics $\mathrm{GmbH})$. PCR conditions were as follows: pre-incubation $\left(95^{\circ} \mathrm{C} \cdot 5 \mathrm{~min}\right)$, amplification $\left(95^{\circ} \mathrm{C} \cdot 10 \mathrm{~s}\right.$, $\left.4.4^{\circ} \mathrm{C} / \mathrm{s}\right),\left(60^{\circ} \mathrm{C} \cdot 25 \mathrm{~s}, 2.2^{\circ} \mathrm{C} / \mathrm{s}\right)$, and $\left(72^{\circ} \mathrm{C} \cdot 1 \mathrm{~s}, 4.4^{\circ} \mathrm{C} / \mathrm{s}\right)$, for 45 - 65 cycles. Data $(n=6)$ were standardized by ratio using the expression of mouse Gapdh as an internal standard.

\subsection{Statistical Analysis}

Statistical significance was evaluated without using oneway ANOVA by unpaired $t$ tests as applicable; $\mathrm{P}<0.05$ was considered statistically significant.

\section{RESULTS}

\subsection{Accumulation of GlcCer in Mop8 Cells under Heat Stress}

After being subjected to heat stress at $42^{\circ} \mathrm{C}$ for $15 \mathrm{~h}$, glycolipids of mouse fibroblast Mop8 cells were metabolically labeled with ${ }^{14} \mathrm{C}$-galactose for $5 \mathrm{~h}$. The neutral glycolipids from Mop8 cells were separated by 2DHPTLC analysis using a two-solvent system. The plates were analyzed by an imaging analyzer or spraying orcinol reagent. Figures 1(a) and (b) show the glycolipid profiles of Mop8 cells in a control culture and heatstressed culture at $42^{\circ} \mathrm{C}$, respectively. GlcCer and LacCer of Mop8 cells co-migrated with their authentic references. The ${ }^{14} \mathrm{C}$-incorporation into $\mathrm{GlcC}$ er in the heatstressed culture increased $20 \%$ compared to the control at $37^{\circ} \mathrm{C}$ (Figure 1(c)), while LacCer decreased to $53 \%$ (Figure 1(d)).

Table 1. Probes and primers for real-time PCR.

\begin{tabular}{|c|c|c|c|c|c|}
\hline Enzyme & Probe \# & Gene & Primers & Sequence & Amplicon (bp) \\
\hline \multirow{2}{*}{ Serine palmitoyltransferase } & 67 & $\begin{array}{c}\text { Sptlc1 } \\
\text { (subunit1) }\end{array}$ & $\begin{array}{l}\text { Left } \\
\text { Right }\end{array}$ & $\begin{array}{c}\text { 5'-ggtgctggtggagatggt-3' } \\
\text { 5'-ggattccttccaaaataagatgg-3', }\end{array}$ & 68 \\
\hline & 17 & $\begin{array}{c}\text { Sptlc2 } \\
\text { (subunit2) }\end{array}$ & $\begin{array}{l}\text { Left } \\
\text { Right }\end{array}$ & $\begin{array}{l}\text { 5'-tcggtgcttcaggaggatac-3, } \\
5 \text { '-gagaatgtgtgcgcaggtag-3, }\end{array}$ & 66 \\
\hline Ceramide synthase 1 & 4 & CerS1 & $\begin{array}{l}\text { Left } \\
\text { Right }\end{array}$ & $\begin{array}{l}\text { 5'-ctcattgcetcttcctacgc-3' } \\
5 \text { '-cagctgcacatcgctgac-3' }\end{array}$ & 84 \\
\hline Ceramide synthase 2 & 50 & CerS2 & $\begin{array}{l}\text { Left } \\
\text { Right }\end{array}$ & $\begin{array}{c}\text { 5'-agaagtgggaaacggagtagc-3' } \\
\text { 5'-ttcccaccagaagtagtcatacaa-3', }\end{array}$ & 95 \\
\hline Ceramide synthase 3 & 19 & CerS3 & $\begin{array}{l}\text { Left } \\
\text { Right }\end{array}$ & $\begin{array}{l}\text { 5'-ggcgatttacattttacttgctg-3' } \\
\text { 5'-ggtcatatgcccatggtttg-3' }\end{array}$ & 75 \\
\hline Ceramide synthase 4 & 67 & CerS4 & $\begin{array}{l}\text { Left } \\
\text { Right }\end{array}$ & $\begin{array}{c}\text { 5'-gcctgcatcttgctttctg-3', } \\
\text { 5'-ctgccacagccactcactc-3', }\end{array}$ & 62 \\
\hline Ceramide synthase 5 & 38 & CerS5 & $\begin{array}{l}\text { Left } \\
\text { Right }\end{array}$ & $\begin{array}{l}\text { 5'-catgccatctggtcctacct-3', } \\
\text { 5'-gcggtcatccttagacacct-3', }\end{array}$ & 78 \\
\hline Ceramide synthase 6 & 48 & CerS6 & $\begin{array}{l}\text { Left } \\
\text { Right }\end{array}$ & $\begin{array}{l}\text { 5'-ggagctgtcattttattggtcttt-3' } \\
\text { 5'-ggaacataatgccgaagtcc-3', }\end{array}$ & 77 \\
\hline Neutral sphingomyelinase 1 & 15 & nSMase1 & $\begin{array}{l}\text { Left } \\
\text { Right }\end{array}$ & $\begin{array}{l}\text { 5'-tcctggaggaggtgtgga-3' } \\
5 \text { '-agaggccactgectatcatc-3' }\end{array}$ & 111 \\
\hline Neutral sphingomyelinase 2 & 17 & nSMase2 & $\begin{array}{l}\text { Left } \\
\text { Right }\end{array}$ & $\begin{array}{l}\text { 5'-tctacctcctcgaccagcac-3' } \\
5 \text { '-tgctgctccagtttgtcatc-3' }\end{array}$ & 110 \\
\hline Sphingomyelin synthase 1 & 48 & SgmS1 & $\begin{array}{l}\text { Left } \\
\text { Right }\end{array}$ & $\begin{array}{c}\text { 5'-ggcatgcatttcaactgttc-3' } \\
\text { 5'-gagcttcattattctccgcact-3', }\end{array}$ & 72 \\
\hline $\begin{array}{l}\text { UDP-glucose ceramide } \\
\text { glucosyltransferase }\end{array}$ & 4 & GlcT & $\begin{array}{l}\text { Left } \\
\text { Right }\end{array}$ & $\begin{array}{c}\text { 5'-gtttcaatccagaatgatcaggt-3' } \\
\text { 5'-aagcattctgaaattggctca-3' }\end{array}$ & 87 \\
\hline
\end{tabular}



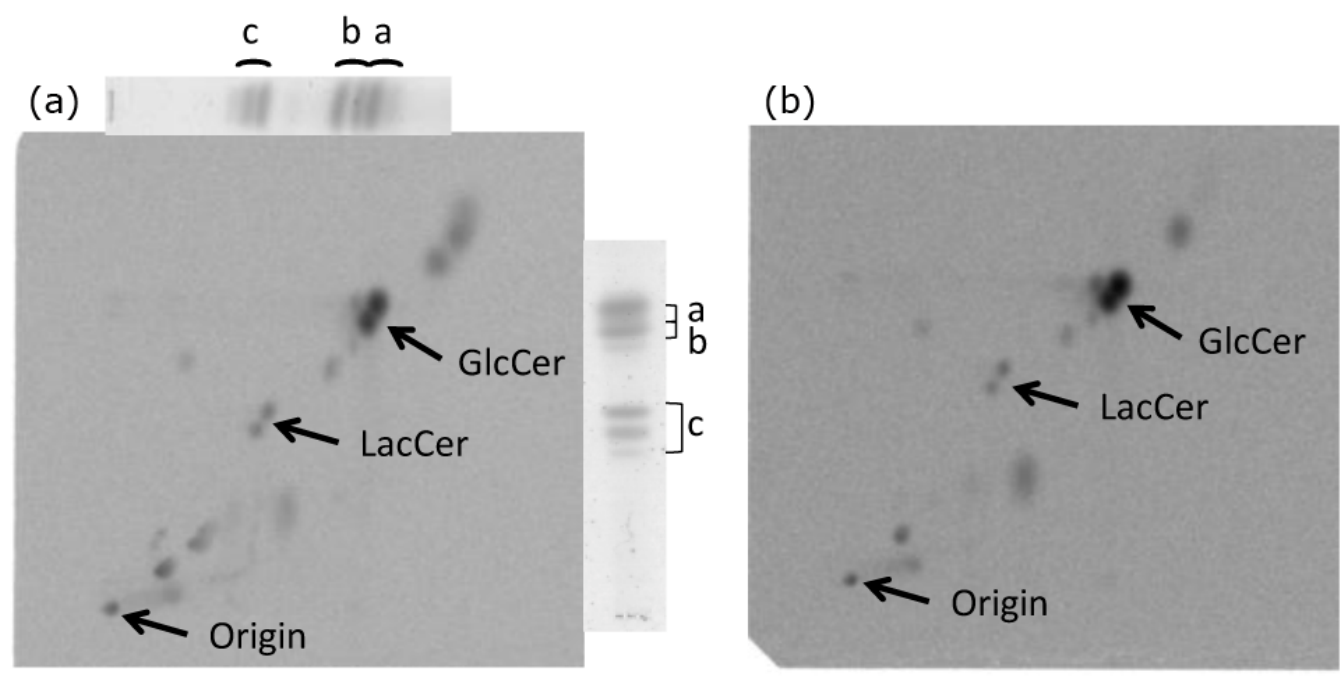

(c)

(d)
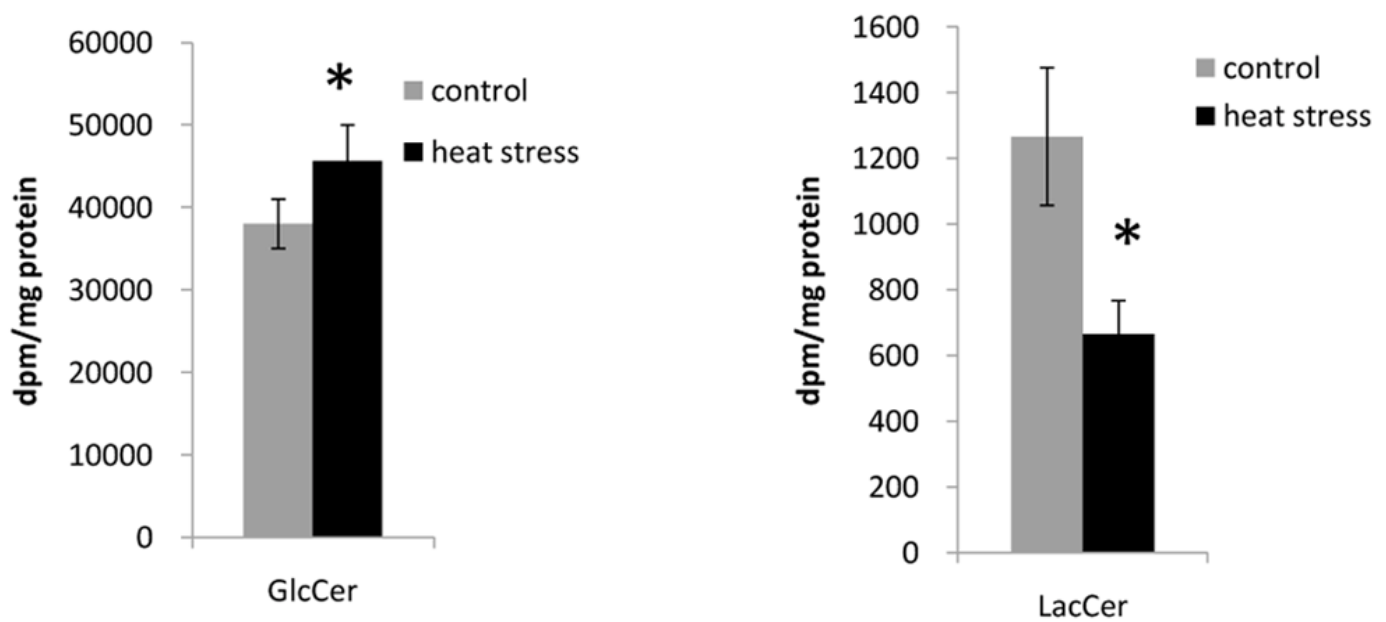

Figure 1. Change of glycolipids profile in Mop8 cells under heat stress. Confluent cells were cultured at $37^{\circ} \mathrm{C}$ and $42^{\circ} \mathrm{C}$ for $15 \mathrm{~h}$. Cells were then labeled with ${ }^{14} \mathrm{C}$-galactose $(37 \mathrm{kBq} / \mathrm{ml})$ at $37^{\circ} \mathrm{C}$ and $42^{\circ} \mathrm{C}$ for $5 \mathrm{~h}$. Neutral glycolipids were prepared as described in the MATERIALS AND METHODS section and developed by 2D HPTLC with chloroform /methanol/water $(60: 25: 4, \mathrm{v} / \mathrm{v})$ in the vertical direction and 2-propanol/ammonium hydroxide/methyl acetate/water $(15: 2: 1: 3, \mathrm{v} / \mathrm{v})$ in the horizontal direction. The ${ }^{14} \mathrm{C}$-incorporation into neutral glycolipids was analyzed with the radio imaging. Reference glycolipids were visualized with spraying the orcinol reagent. (a) control culture at $37^{\circ} \mathrm{C}$, a; GlcCer (horse kidney), b; GalCer (bovine brain), c; LacCer (human kidney), (b) heat stress at $42^{\circ} \mathrm{C}$, (c) incorporation into GlcCer, (d) incorporation into LacCer. *Significance difference, $<0.05(\mathrm{n}=4)$.

\subsection{Cer Increment and Phospholipid Metabolism under Heat Stress}

Cer and phospholipids extracted from cells were analyzed by HPTLC using a two-step development process with two solvent systems. Heat stress at $42^{\circ} \mathrm{C}$ for $16 \mathrm{~h}$ on Mop8 cells increased the incorporation of ${ }^{14} \mathrm{C}$-serine into Cer by $17 \%$ compared to the control culture at $37^{\circ} \mathrm{C}$, while incorporation into phospholipids (PE, PS, and SM) decreased significantly under heat stress (Figure 2(a), (b)). Cer content was also determined by spraying pri- muline reagent. An increase of $23 \%$ was observed under heat stress (Figure 2(c)).

\subsection{Analysis of Sphingolipid Molecular Species by MALDI-TOF MS}

Cer prepared from HPTLC was analyzed by MALDITOF MS. Cer from unstressed cells showed 4 ion peaks at $\mathrm{m} / \mathrm{z} 560.23$ (peak height: 100 ), $\mathrm{m} / \mathrm{z} 644.30$ (peak height: 13), $\mathrm{m} / \mathrm{z} 670.30$ (peak height: 80 ) and $\mathrm{m} / \mathrm{z} 672.30$ (peak height: 46), whereas that from heat stressed cells showed the ion peaks at $\mathrm{m} / \mathrm{z} 560.17$ (peak height: 100), 


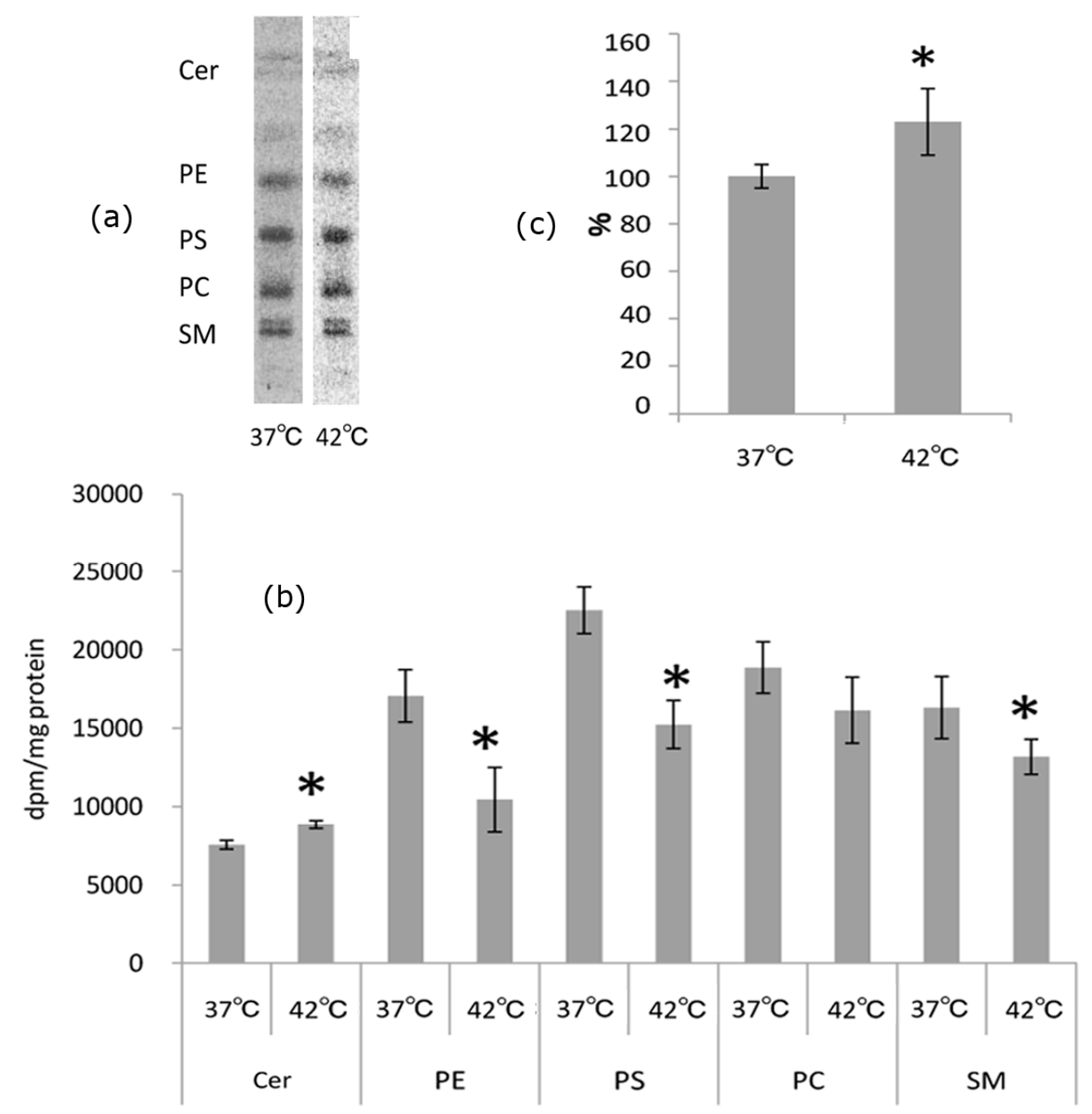

Figure 2. Changes of Cer and phospholipids metabolism under heat stress. Confluent cells were cultured with ${ }^{14} \mathrm{C}$-serine $(37 \mathrm{kBq} / \mathrm{ml})$ at $37^{\circ} \mathrm{C}$ and $42^{\circ} \mathrm{C}$ for $16 \mathrm{~h}$. Total lipids prepared as described in the MATERIALS AND METHODS section were separated by HPTLC with chloroform/methanol/acetic acid (9:1:1, $\mathrm{v} / \mathrm{v}$ ) in the first run, the plate was dried and then re-developed with chloroform/methanol/acetic acid/ water $(25: 15: 4: 2, \mathrm{v} / \mathrm{v})$ until $65 \%$ of the solvent top of the first run. (a) representative TLC imaging patterns of lipids, (b) ${ }^{14} \mathrm{C}$-incorporation into lipids, (c) Cer content determined by primuline reagent. *Significance difference, $<0.05(\mathrm{n}=4)$.

$\mathrm{m} / \mathrm{z} 644.23$ (peak height: 15$), \mathrm{m} / \mathrm{z} 670.22$ (peak height: 26) and $\mathrm{m} / \mathrm{z} 672.26$ (peak height: 14) (Figures 3(a) and (b), Table 2).

Cer at $\mathrm{m} / \mathrm{z} 560$ corresponds to a sodiated molecular ion composed of d18:1 as a long chain base and C16:0 as a fatty acid. MS/MS analysis of $\mathrm{m} / \mathrm{z} 560$ with high-energy CID fragmentation showed typical fragments $\mathrm{m} / \mathrm{z} 264$ and $\mathrm{m} / \mathrm{z} 376$ derived from d18:1, and $\mathrm{m} / \mathrm{z} 304$ from C16:0 (Figure 3(c)) [25]. Ions ( $\mathrm{m} / \mathrm{z} \mathrm{390,} \mathrm{404,} \mathrm{418,} \mathrm{432,} \mathrm{446,}$ $460,474,488,516$ and 544) with a difference of $14 \mathrm{Da}$ (-CH2-) between ions were observed between 560 and 376, indicating the ions derived from C16:0 and d18: 1 . Cer at $\mathrm{m} / \mathrm{z} 670$ and $\mathrm{m} / \mathrm{z} 672$ corresponds to sodiated molecular ions composed of $\mathrm{d} 18: 1$ as a long chain base and
C24:1 and C24:0 as fatty acids, respectively. Further, the analysis of $m / z 670$ - 672 with CID fragmentation revealed $\mathrm{m} / \mathrm{z} 264$ (not shown) and $\mathrm{m} / \mathrm{z} 376$ derived from $\mathrm{d} 18: 1$, and $\mathrm{m} / \mathrm{z} 416$ from C24:0, (Figure 3(d)) [25]. While it was hard to detect $\mathrm{m} / \mathrm{z} 414$ derived from $\mathrm{C} 24: 1$, molecular ion $\mathrm{m} / \mathrm{z} 670$ was speculated as d18:1 - C24:1 from the metabolic relationship. Ion peak of Cer at $\mathrm{m} / \mathrm{z}$ 644 was tentatively assigned as a sodiated molecular ion composed of d18:1 as a long chain base and C22:0 as a fatty acid, and the ratio of the peak height to that of $\mathrm{m} / \mathrm{z}$ 670 (d18:1 - C24:1, Cer) and m/z 672 (d18:1 - C24:0, Cer) was higher in heat stressed cells than in the control cells (Figure 3(a) and (b)). These results suggested that d18:1 $\mathrm{C} 16: 0$ and d18:1 - C22:0 Cer species increased 


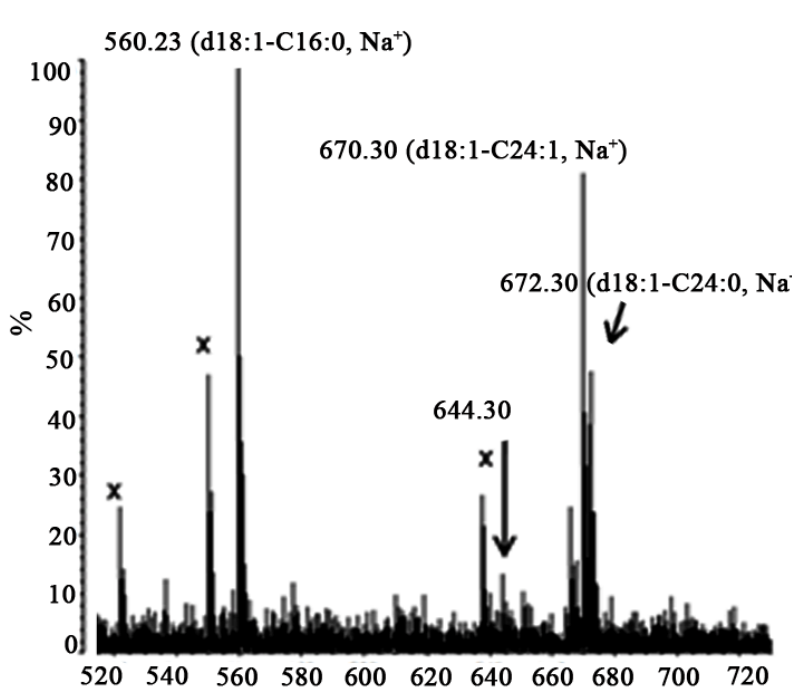

(a) $\mathrm{m} / \mathrm{z}$

304.17
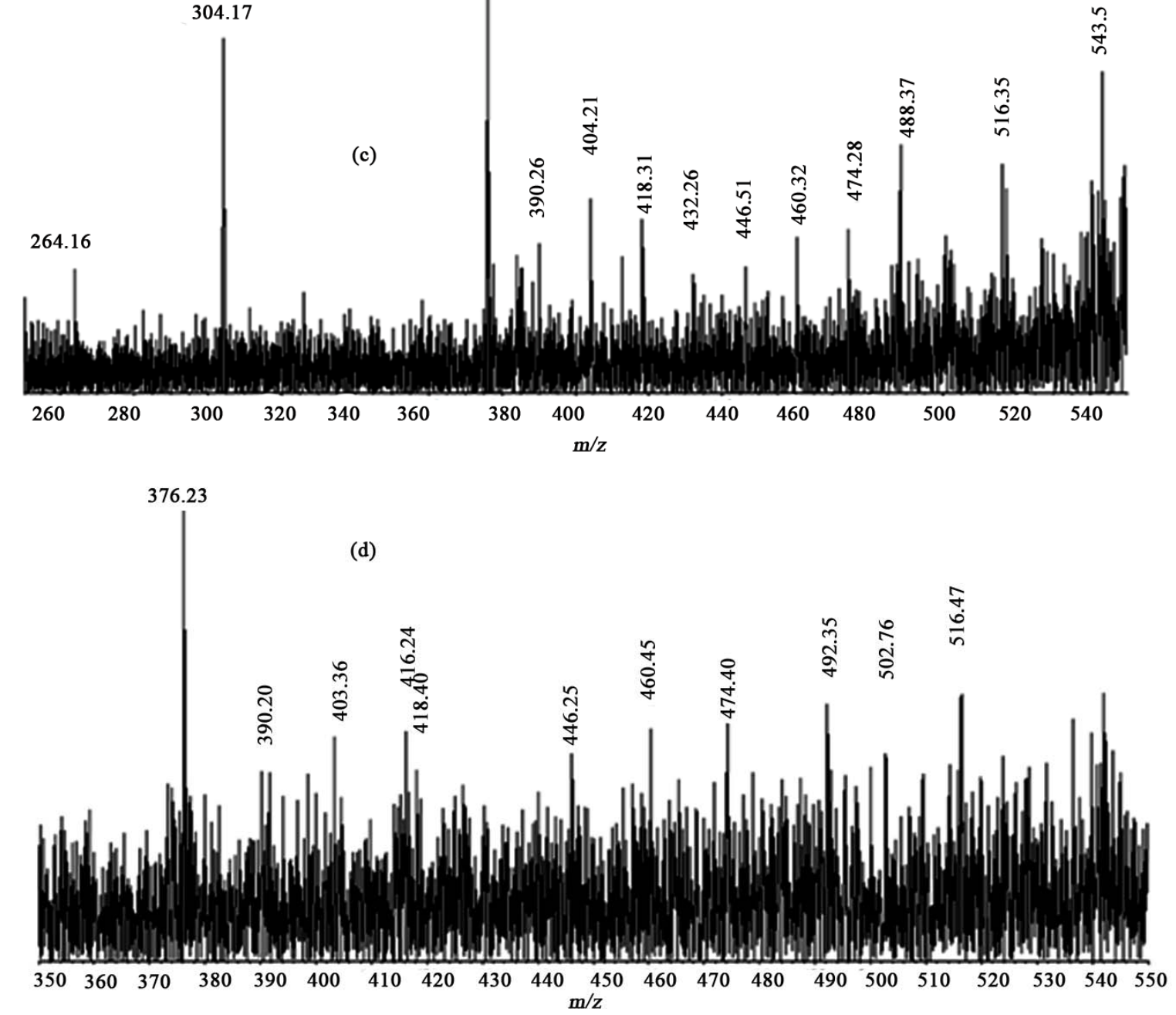

Figure 3. Analysis of Cer with MALDI-TOF MS. (a) Cer from control cells, (b) Cer from heat-stressed cells at $42^{\circ} \mathrm{C}$, (c) analysis of $\mathrm{m} / \mathrm{z} 560$ with CID, (d) analysis of $\mathrm{m} / \mathrm{z} 670$ - 672 with CID. $\mathrm{x}$; unidentified peak. 
Table 2. Molecular ion species in Cer and GlcCer.

\begin{tabular}{|c|c|c|c|c|c|c|c|c|}
\hline \multirow[b]{3}{*}{ molecular species in Cer moiety } & \multicolumn{4}{|c|}{ Cer } & \multicolumn{4}{|c|}{ GlcCer } \\
\hline & \multicolumn{2}{|c|}{ control } & \multicolumn{2}{|c|}{ heat stress } & \multicolumn{2}{|c|}{ control } & \multicolumn{2}{|c|}{ heat stress } \\
\hline & $\mathrm{m} / \mathrm{z}$ & peak height & $\mathrm{m} / \mathrm{z}$ & peak height & $\mathrm{m} / \mathrm{z}$ & peak height & $\mathrm{m} / \mathrm{z}$ & peak heigh \\
\hline$\left(\mathrm{d} 18: 1-\mathrm{C} 16: 0, \mathrm{Na}^{+}\right)$ & 560.23 & 100.0 & 560.17 & 100.0 & 722.60 & 100.0 & 722.61 & 100.0 \\
\hline$\left(\mathrm{d} 18: 1-\mathrm{C} 16: 0(\mathrm{OH}), \mathrm{Na}^{+}\right)$ & - & - & - & - & 738.58 & 61.0 & 738.57 & 139.0 \\
\hline$\left(\mathrm{d} 18: 1-\mathrm{C} 18: 0, \mathrm{Na}^{+}\right)$ & - & - & - & - & 750.64 & 5.4 & 750.64 & 7.8 \\
\hline$\left(\mathrm{d} 18: 1-\mathrm{C} 18: 0(\mathrm{OH}), \mathrm{Na}^{+}\right)$ & - & - & - & - & 766.61 & 3.6 & 766.60 & 8.1 \\
\hline$\left(\mathrm{d} 18: 1-\mathrm{C} 20: 0, \mathrm{Na}^{+}\right)$ & - & - & - & - & 778.67 & 4.2 & 778.66 & 5.0 \\
\hline$\left(\mathrm{d} 18: 1-\mathrm{C} 20: 0(\mathrm{OH}), \mathrm{Na}^{+}\right)$ & - & - & - & - & 794.65 & 2.8 & 794.63 & 7.2 \\
\hline$\left(\mathrm{d} 18: 1-\mathrm{C} 22: 0, \mathrm{Na}^{+}\right)$ & 644.30 & 13.0 & 644.23 & 15.0 & 806.70 & 6.0 & 806.70 & 7.8 \\
\hline$\left(\mathrm{d} 18: 1-\mathrm{C} 22: 0(\mathrm{OH}), \mathrm{Na}^{+}\right)$ & - & - & - & - & 822.68 & 4.2 & 822.67 & 11.9 \\
\hline$\left(\mathrm{d} 18: 1-\mathrm{C} 24: 1, \mathrm{Na}^{+}\right)$ & 670.30 & 80.0 & 670.22 & 26.0 & 832.71 & 7.2 & 832.71 & 18.3 \\
\hline$\left(\mathrm{d} 18: 1-\mathrm{C} 24: 0, \mathrm{Na}^{+}\right)$ & 672.30 & 46.0 & 672.26 & 14.0 & 834.72 & 9.2 & 834.72 & 17.5 \\
\hline$\left(\mathrm{d} 18: 1-\mathrm{C} 24: 1(\mathrm{OH}), \mathrm{Na}^{+}\right)$ & - & - & - & - & 848.69 & 5.6 & 848.68 & 27.8 \\
\hline$\left(\mathrm{d} 18: 1-\mathrm{C} 24: 0(\mathrm{OH}), \mathrm{Na}^{+}\right)$ & - & - & - & - & 850.70 & 7.2 & 850.69 & 25.0 \\
\hline
\end{tabular}

more than d18:1 - C24:1 Cer and d18:1 - C24:0 Cer in heat stressed cells. The changes of molecular species of GlcCer and SM under heat stress were also analyzed. Molecular ion species of GlcCer showed a wide spectrum of fatty acyl chain compared with that of Cer. Sodiated molecular ions consisting of a hexose, d18:1 as a long chain base and a fatty acid corresponding to $\mathrm{C} 16: 0$, C16:0 (OH), C18:0, C18:0 (OH), C20:0, C20:0 (OH), $\mathrm{C} 22: 0, \mathrm{C} 22: 0(\mathrm{OH}), \mathrm{C} 24: 0, \mathrm{C} 24: 0(\mathrm{OH}), \mathrm{C} 24: 1$ and $\mathrm{C} 24$ : $1(\mathrm{OH})$, respectively, were detected in both control and heat stress-ed cells (Figures 4 (a) and (b)).

The MS/MS analysis of $m / z 722.60$ with CID fragmentation revealed $\mathrm{m} / \mathrm{z} 304.15$ derived from a fatty acid $\mathrm{C} 16: 0$ and $\mathrm{m} / \mathrm{z} 539.72$ from d18: 1 as a long chain base (Figure 4). The relative peak height of each molecular ion to (d18:1 - C16:0, $\mathrm{Na}^{+}$) was obtained (Table 2 ). The relative peak ratio of each GlcCer consisting of hydroxy fatty acid to that consisting of non-hydroxy fatty acid increased 2-5-fold in heat stressed cells compared with that in control cells. Whereas, the analysis of SM molecular species demonstrated several molecular ions identified as indicated in Figure 4(d) between $\mathrm{m} / \mathrm{z} 700$ and $\mathrm{m} / \mathrm{z} 860$ with a small difference in control and heat stressed cells (Figures 4(d) and (e)). The major ion peak was $\mathrm{m} / \mathrm{z}$ 725(d18:1-C16:0, $\left.\mathrm{Na}^{+}\right)$.

\subsection{Activation of Cer-Related Genes and HSP70 Gene under Heat Stress}

We investigated the effects of heat stress on selected genes. Spt, known as a first-step enzyme in de novo synthesis of Cer, is composed of two subunits: Sptlc1 and Sptlc2. We found the activation of both Sptlc1 and Sptlc2 genes (at $42^{\circ} \mathrm{C}$ for $16 \mathrm{~h}$ ) to be 2.67 -fold and 2.84 fold, respectively (Figure 5(a)). In a time-dependent experiment, the Sptlc1 gene increased by 1.64 -fold at $8 \mathrm{~h}$ and 2.67-fold at 16h (Figure 5(b)). Expression of 6 CerS genes (CerS1-CerS6) known from mouse tissues, was investigated under heat stress. The CerS genes were significantly activated at $42^{\circ} \mathrm{C}$ to 23.82 -fold (CerS1), 2.70fold (CerS2), 2.17-fold (CerS4), 1.92-fold (CerS5) and 2.41-fold (CerS6), while CerS3 was not significantly activated at $42^{\circ} \mathrm{C}$. Only CerS6 gene was activated to 1.24-fold at $40^{\circ} \mathrm{C}$ (Figures 6(a)-(f)). The expression levels $\left(10^{-3}\right.$ or $\left.10^{-2}\right)$ of CerS4-CerS6 to the reference gene were much higher than those $\left(10^{-7}\right)$ of CerS1-CeS3.

The nSMase1, nSMase2, and SgmS1 genes were also activated to 2.17-fold, 3.02-fold, and 1.65-fold, respectively, at $42^{\circ} \mathrm{C}$ (Figures 7(a)-(c)) but not at $40^{\circ} \mathrm{C}$. The GlcT gene was significantly activated to 1.22 -fold at $40^{\circ} \mathrm{C}$ and 1.60 -fold at $42^{\circ} \mathrm{C}$ (Figure 7(d)). The GlcT gene was activated to 1.41 -fold at $8 \mathrm{~h}$ and 1.60 -fold at $16 \mathrm{~h}$ (Figure 7(e)). The HSP70 gene as a marker of heat stress was also enhanced to 3.44 -fold at $42^{\circ} \mathrm{C}$, but not at $40^{\circ} \mathrm{C}$ (Figure 7(f)). 

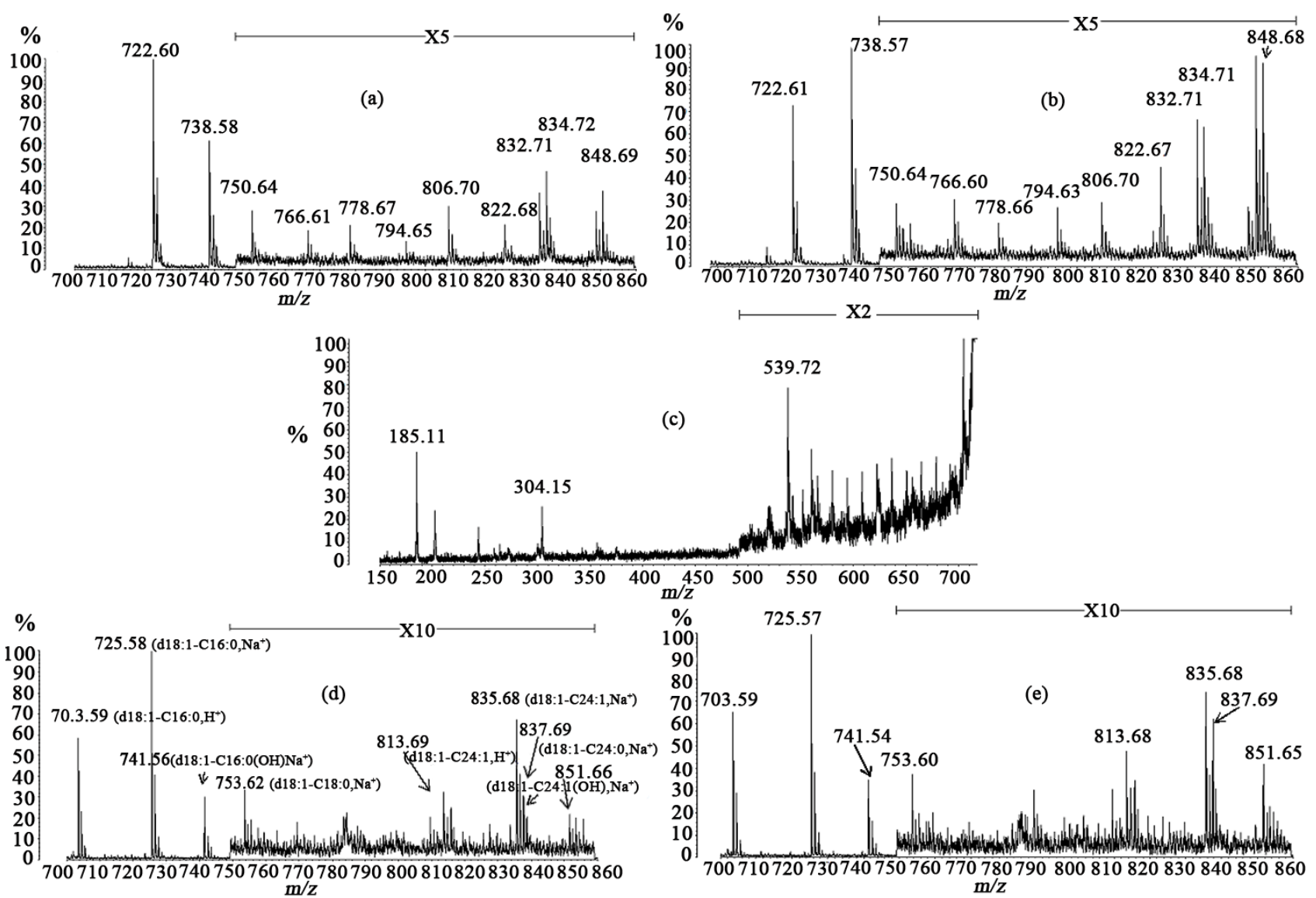

Figure 4. Analysis of GlcCer and SM with MALDI-TOF MS. (a) GlcCer from control cells, (b) GlcCer from heat-stressed cells at $42^{\circ} \mathrm{C}$, (c) analysis of $\mathrm{m} / \mathrm{z} 722$ with CID, (d) SM from control cells, (e) SM from heat-stressed cells at $42^{\circ} \mathrm{C}$.

(a)

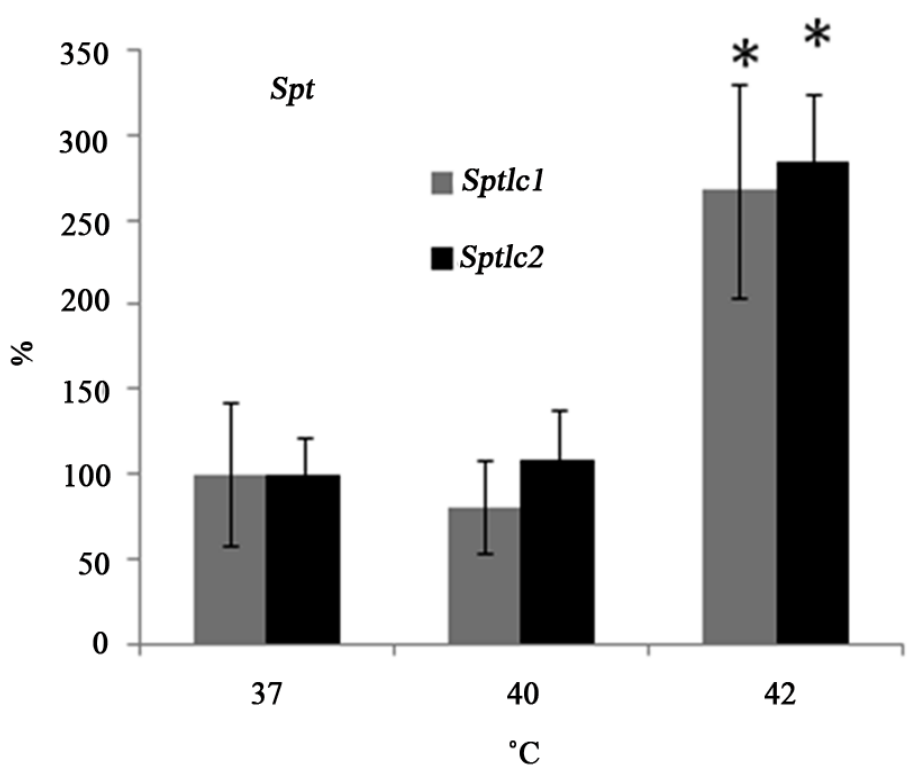

(b)

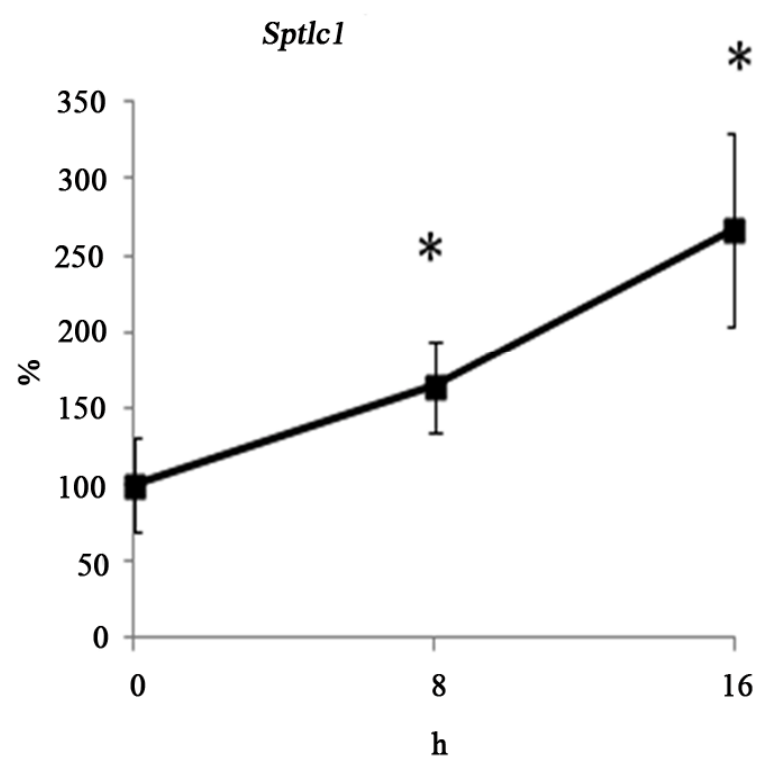

Figure 5. Activation of Spt gene in Mop8 cells under heat stress. Confluent Mop8 cells were cultured at 37,40 and $42^{\circ} \mathrm{C}$ for $16 \mathrm{~h}$. Total RNAs were prepared and used for quantitative RT-PCR as described in the MATERIALS AND METHODS section. (a) Sptlc1 gene and Sptlc2 gene, (b) time-dependent activation of Sptlc1 gene. 

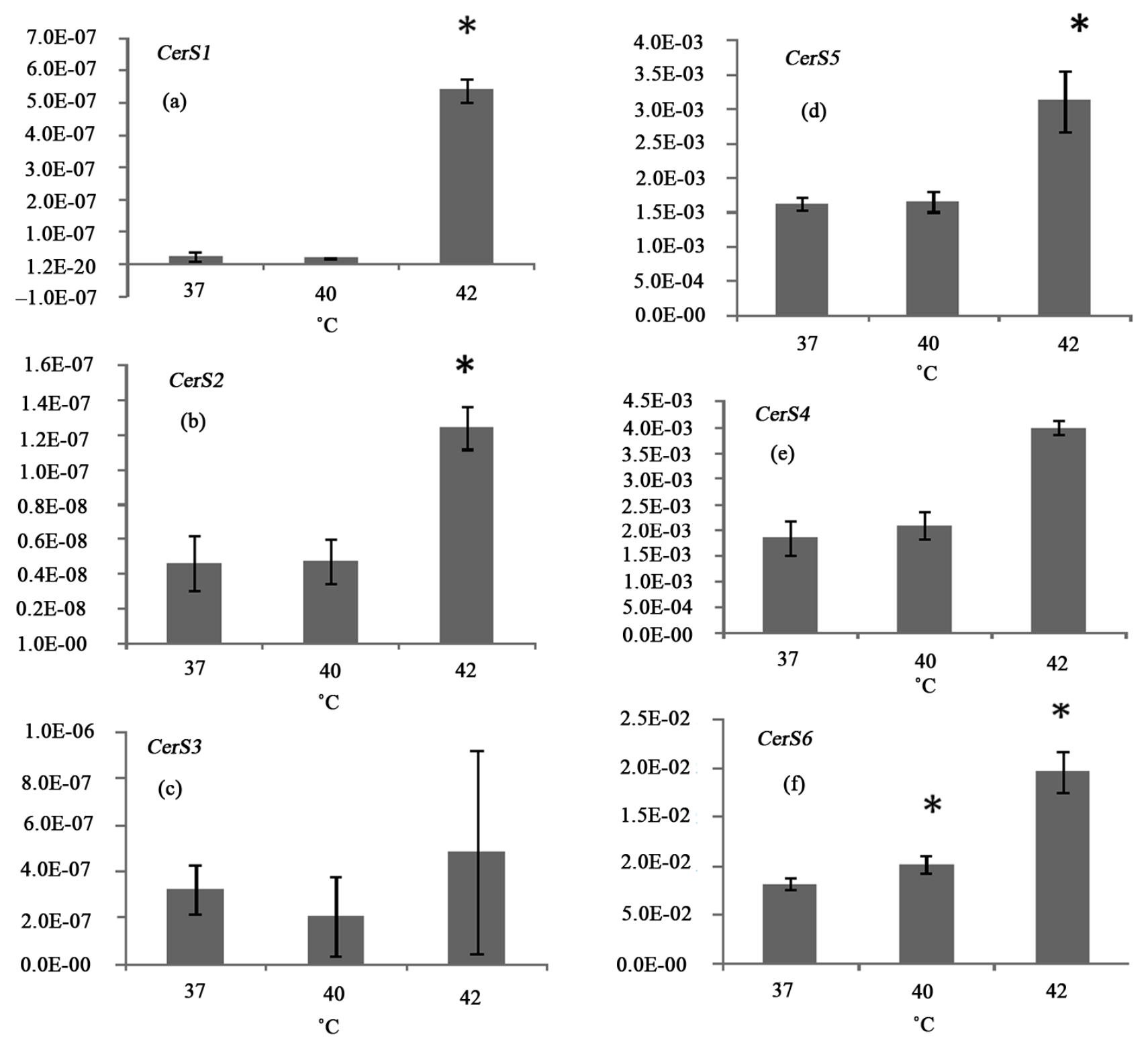

Figure 6. Expression of CerS genes under heat stress. (a) CerS1, (b) CerS2, (c) CerS3, (d) CerS4, (e) CerS5, (f) CerS6. Longitudinal axis represents the ratio of a target gene to Gapdh as a reference gene. * Significance difference, $<0.05(n=6)$.

\section{DISCUSSION}

Cer is a major bioactive lipid in eukaryotic cells [2]. In addition to its structural significance as a membrane component, it is believed to be involved in a variety of cellular functions including the regulation of cell growth, differentiation, and viability. It is well known that vari-ous stresses such as high temperature and ultraviolet (UV) radiation elevate intracellular Cer levels followed by cell apoptosis $[4,5]$. We found that hypertonic stress elicited the syntheses of both Cer and GalCer in kidney cells [20]. In our recent study [22], heat stress on MDCK cells increased Cer content and its de novo synthesis from serine. Both GlcCer and GalCer syntheses from Cer, which are the first glycosylation steps of sphingolipid metabolism in kidney cells, also increased with the activation of both GlcT and GalT genes. Thus, we speculated that accumulation of Cer under heat stress might be a trigger to activate the synthesis of monohexosylceramides (GalCer and/or GlcCer) to decrease its level and evade cell apoptosis. In the present study, we confirmed that the increment of Cer and its subsequent glycosylation also occurred in mouse fibroblast Mop8 cells under heat stress.

The enzyme genes of Spt, CerS1, CerS2, CerS4, CerS5, CerS6, nSMase1, and nSMase2 relevant to the elevation of intracellular Cer contents were shown to be activated under heat stress at $42^{\circ} \mathrm{C}$. On the other hand, the 
message signals of SgmS1 and GlcT corresponding to lowering the Cer level were also activated. Cer is newly synthesized at the cytosolic surface of the endoplasmic reticulum from serine and palmitoyl-CoA, which condense to form 3-ketosphinganine through the action of Spt [26], followed by a rapid reduction to sphinganine by 3-ketosphinganine reductase. Synthesis of more complex
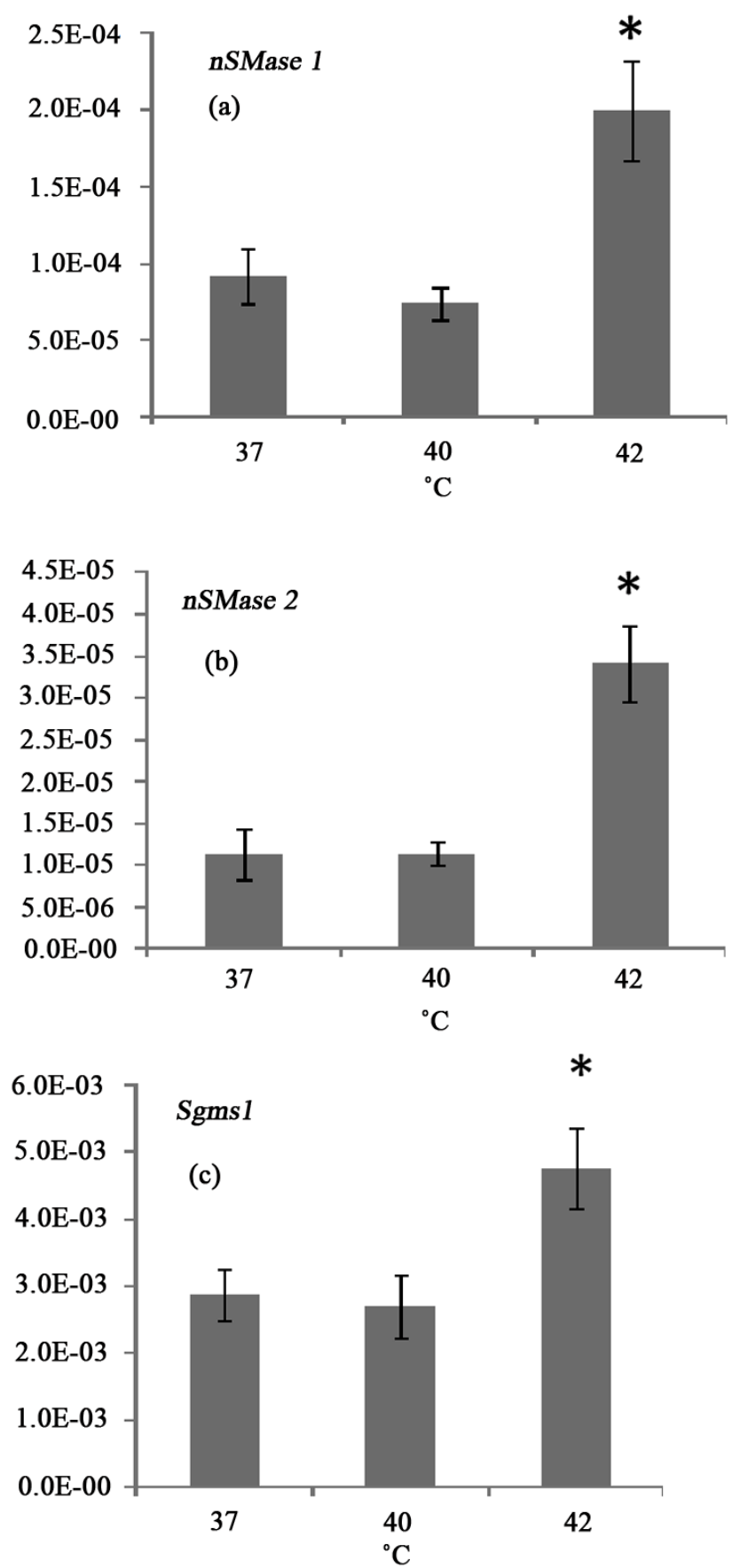

sphingolipid metabolites such as SM and GlcCer is carried out in the Golgi apparatus [4]. Heatshock-induced Cer accumulation in mammalian cells is known to take place during de novo synthesis [16]. The activation of GlcT and SgmS under heat stress suggests that heat stress may affect activation of enzymes in the Golgi in addition to those in the endoplasmic reticulum.
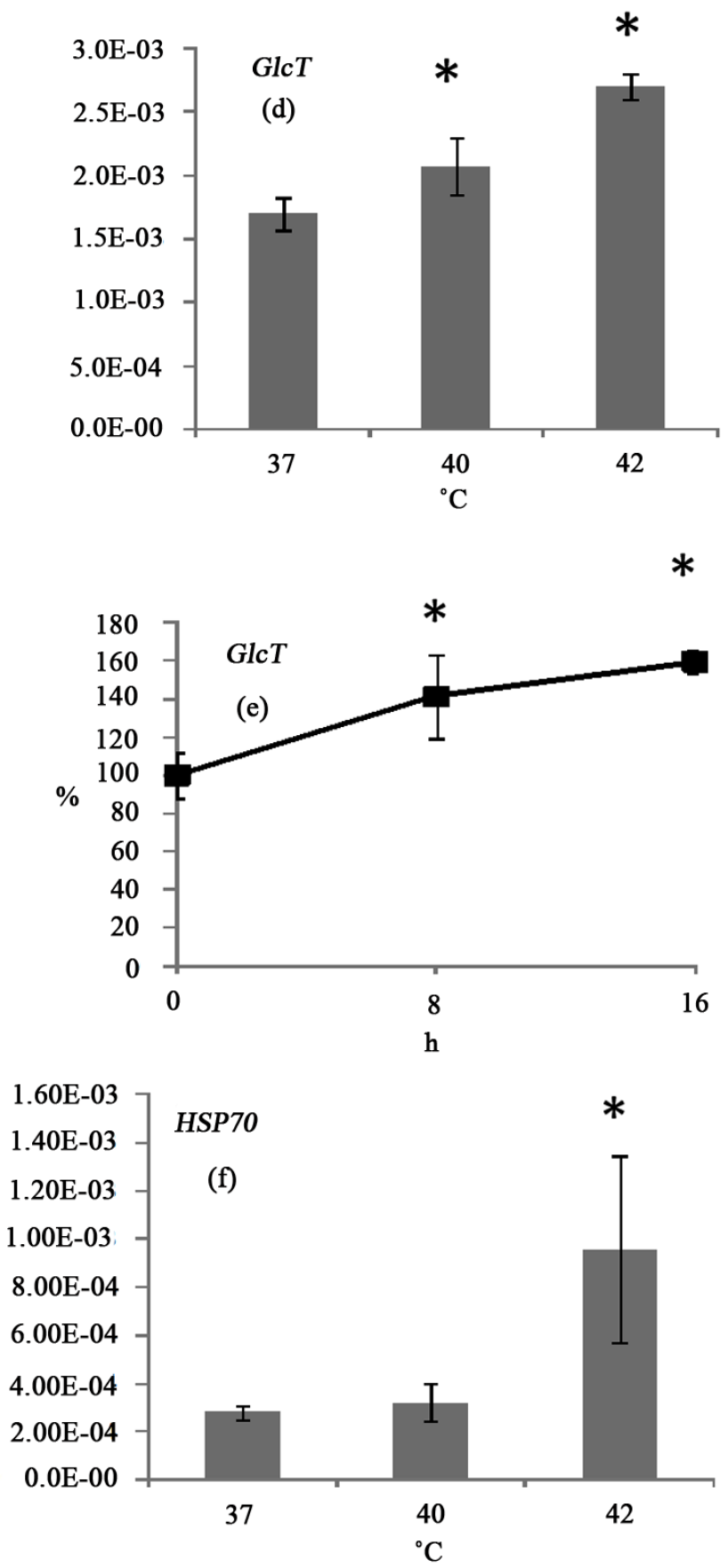

Figure 7. Expression of sphingolipid-related genes and HSP70 gene under heat stress. (a) nSMase1, (b) nSMase2, (c) SgmS1, (d) GlcT, (e) time-dependent activation of GlcT gene, (f) HSP70. Longitudinal axis represents the ratio of a target gene to Gapdh as a reference gene. $*$ Significance difference, $<0.05(\mathrm{n}=6)$. 
Cer homeostasis is also dependent on de novo synthesis of Cer from sphinganine and acyl CoA, catalyzed by a family of six CerS (CerS1-6). These enzymes are products different genes and preferentially use different fatty acyl CoA substrates containing fatty acid chains of different lengths, thereby producing Cer with different acyl chains [27]. CerS1 is a mammalian homolog of the yeast longevity assurance gene 1 . It has been shown in yeast that longevity assurance gene members play a role in the regulation of life span and are also required for CerS activity. Recent studies also revealed that one of the mouse homologs of these proteins specifically regulates the synthesis of stearoyl (C18)-containing sphingolipids, including C18-Cer [28]. CerS1 is the most structurally and functionally distinct enzyme among the members and the level of CerS1 is specifically controlled via ubiquitination and proteasome-dependent protein turnover. Both endogenous and ectopically expressed CerS1 have rapid basal turnover, and diverse stresses including chemotherapeutic drugs, UV light, and DTT can cause increased turnover of CerS1 [29]. In our experiment the highest expression of the CerS1 gene at $42^{\circ} \mathrm{C}$ seemed to reflect the greatest heat stress sensitivity among the Cer-related genes investigated. However, the significance of higher response of CerS1 to heat stress is unclear because GlcCer and SM consisted of C18 fatty acyl chain corresponding to this gene have been detected weakly in this cell line, but not in Cer. CerS2 mRNA has the broadest tissue distribution, and synthesizes Cer containing mainly $\mathrm{C} 20-\mathrm{C} 26$ fatty acids, with little or no synthesis of C16- and C18-Cer [30].

The molecular heterogeneity of Cer synthesized in the epidermis and their possible roles in epidermal permeability barrier functions have also been investigated [31]. The expressions of CerS2, CerS4, CerS5 and CerS6 were enhanced at lower extent than that of CerS1. From the result that the expression levels of CerS4-CerS6 to the reference gene were much higher than those of CerS1-CerS3 in both control and heat-stressed cells, the enzyme activities of CerS4-CerS6 may greatly affect the composition of fatty acid moieties of Cer under heat stress. CerS5 and CerS6 have been known to use C16$\mathrm{CoA}$ as a substrate, while CerS2 could use C24:0-CoA and C24:1-CoA [32]. CerS5 and/or CerS6 may contribute to the Cer (d18:1-C16:0) accumulation under heat stress in this cell line. CerS2 may also contribute to the increase of GlcCer containing C24:0 or C24:1 under heat stress in this cell line. The relationship between the enzyme activities of CerS members and the fatty acyl chain of Cer should be analyzed further. Hydroxy fatty acyl chains were detected from GlcCer and SM. All CerS members can synthesize 2-hydroxy fatty acyl-Cer with specificity for 2-hydroxy-fatty acyl-CoA chain length
[33]. A gene of a fatty acid 2-hydroxylase (FA2H), which forms 2-hydroxy fatty acids from non-hydroxy fatty acids, has been characterized [34]. Activation of FA2H under heat stress may contribute to the enhancement of hydroxyl fatty acid molecular species of GlcCer. We previously reported the increment of hydroxy fatty acid species in sulfatide and GalCer under hyperosmotic stress in kidney cells [35]. Although, little is known about the significance of hydroxy fatty acid molecular species of sphingolipids, their hydrophilic properties increase the hydroxy bonds in the bilayer of the plasma membrane. Enrichment of Cer with a short chain fatty acid and GlcCer with hydroxy fatty acyl chains under heat stress may reduce the hydrophobicity of the lipid molecule, and increase the membrane fluidity and affect the properties of the cell membrane to adapt to stresscondition.

A report has suggested that Cer was generated by SM hydrolysis by heat-shock-activated, magnesium-depen dent nSMase [36]. Consistent with the report, both nSMase 1 and nSMase2 were revealed to be upregulated under heat stress in our experiment. SM hydrolysis in response to stress-inducing agents and subsequent $\mathrm{Cer}$ generation are implicated in various cellular responses, including apoptosis, inflammation, and proliferation, depending on the nature of the different aSMases or nSMases. The nSMases are activated by a variety of stress-inducing agents including cytokines, oxidative stress $\left(\mathrm{H}_{2} \mathrm{O}_{2}\right.$, oxidized lipoproteins), UV radiation, chemotherapeutic drugs, amyloid peptides, and lipopolysaccharides [37]. In mammals, $\mathrm{Mg}^{2+}$-dependent nSMases, nSMase1, nSMase2, and nSMase3, have been identified. Among these enzymes, nSMase 2 is most studied and has been implicated in multiple physiological responses including cell growth arrest, apoptosis, development, and inflammation [38]. The nSMase1 knockout mice showed no abnormality in sphingolipid metabolism or lipid storage disease [39].The physiologic role of nSMase1 is still unclear and further elucidation is necessary; however, nSMase2 has emerged as a major candidate for stress-induced Cer production and a number of anti-cancer drugs have been shown to exert effects on nSMase2. In MCF-7 breast cancer cells, daunorubicin upregulated cellular nSMase activity and Cer levels [40]. Other reports have also suggested that nSMase 2 plays a role in stress-induced bronchial and lung injury in pulmonary diseases [41,42]. In mammalian cells the bulk of Cer is converted to SM by SgmS1 in the lumen of the transGolgi. This enzyme catalyzes the transfer of phosphocholine from PC to Cer. A second SgmS, SgmS2, resides at the plasma membrane, but it is unclear whether this enzyme participates in de novo synthesis of SM [43]. It could be expected that activation of anabolic SgmS1 and 
catabolic nSMase1 and nSMase2 under heat stress caused the enhancement of SM turnover in our experiment. In fact, we observed a significant decrease of SM radioactivity to $81 \%$ at $42^{\circ} \mathrm{C}$ which coincided with the total increase of $17 \%$ of serine incorporation into Cer or the increase of $23 \%$ of Cer content (Figure 2). SMaseinduced stress initiates a response in keratinocytes that includes upregulation of GlcCer synthesis which may protect against the deleterious effects of excess Cer [19]. In PDMP (1-phenyl-2-decanoylamino-3-morpholino-1-propanol) treated cells there is a decrease in the amount of cellular GlcCer and other GlcCer-based glycolipids, whereas the amount of Cer increases $[44,45]$. The induction of Cer accumulation by various triggers of Cer generation elicits the activation of caspase-3. This elevation of Cer levels also induces cleavage of the death substrate poly (ADP-ribose) polymerase followed by apoptotic cell death [46]. The significance of GlcCer synthase in apoptosis and drug resistance has been investigated $[47,48]$. We previously reported that the GlcT gene was activated in kidney cells under heat stress and the synthesis of GlcCer was enhanced by the introduction of HSP70 gene into the cells [22]. In the present study, we confirmed that the GlcT gene in fibroblasts was activated in a temperature-dependent manner under heat stress. This activation of GlcT induced an increase of GlcCer, resulting in a decrease in intracellular Cer. The salvage of Cer may prevent cell apoptosis. However, another reason for the accumulation of GlcCer may be caused of decrease of LacCer synthesis from GlcCer as shown in the metabolic labeling. Activation of sphingolipid-related genes under heat stress seems to correlate with the activation of HSP70 gene. The precise mechanism underlying the activation of these genes remains to be elucidated.

\section{REFERENCES}

[1] Hannun, Y.A. and Luberto, C. (2000) Ceramide in the eukaryotic stress response. Trends in Cell Biology, 10, 73-80. doi:10.1016/S0962-8924(99)01694-3

[2] Hannun, Y. A. and Obeid, L. M. (2008) Principles of bioactive lipid signalling: Lessons from sphingolipids. $\mathrm{Na}$ ture Reviews Molecular Cell Biology, 9, 139-150. doi:10.1038/nrm2329

[3] Yang, J., Sun, Y., Yu, S. and Duerksen-Hughes, P.J. (2004) Ceramide and other sphingolipids in cellular responses. Cell Biochemistry and Biophysics, 40, 323-350. doi:10.1385/CBB:40:3:323

[4] Bartke, N. and Hannun, Y.A. (2009) Bioactive sphingolipids: Metabolism and function. Journal of Lipid Research, 50, S91-S96. doi:10.1194/jlr.R800080-JLR200

[5] Nikolova-Karakashian, M.N. and Rozenova, K.A. (2010) Ceramide in stress response. Advances in Experimental Medicine and Biology, 688, 87-108. doi:10.1007/978-1-4419-6741-1 6

[6] Okazaki, T., Bell, R.M. and Hannun, Y.A. (1989) Sphingomyelin turnover induced by vitamin D3 in HL-60 cells, Role in cell differentiation. Journal of Biological Chemistry, 264, 19076-19080.

[7] Venable, M.E., Lee, J.Y., Smyth, M.J., Bielawska, A. and Obeid, L.M. (1995) Role of ceramide in cellular senescence. Journal of Biological Chemistry, 270, 3070130708. doi:10.1074/jbc.270.51.30701

[8] Hetz, C.A., Hunn, M., Rojas, P., Torres, V., Leyton, L. and Quest, A.F. (2002) Caspase-dependent initiation of apoptosis and necrosis by the Fas receptor in lymphoid cells: Onset of necrosis is associated with delayed ceramide increase. Journal of Cell Science, 115, 4671-4683. doi: $10.1242 /$ jes. 00153

[9] Adam, D., Heinrich, M., Kabelitz, D. And Schutze, S. (2002) Ceramide: Does it matter for T cells? Trends in Immunology, 23, 1-4. doi:10.1016/S1471-4906(01)02091-9

[10] Obeid, L.M., Linardic, C.M., Karolak, L.A. and Hannun, Y.A. (1993) Programmed cell death induced by ceramide. Science, 259, 1769-1771. doi:10.1126/science.8456305

[11] Schenck, M., Carpinteiro, A., Grassmé, H., Lang, F. and Gulbins, E. (2007) Ceramide: Physiological and pathophysiological aspects. Archives of Biochemistry and Biophysics, 462, 171-175. doi:10.1016/j.abb.2007.03.031

[12] Schiffmann, S., Sandnery, J., Birod, K., et al. (2009) Ceramide synthases and ceramide levels are increased in breast cancer tissue. Carcinogenesis, 30, 745-752. doi:10.1093/carcin/bgp061

[13] Kondo, T., Matsuda, T., Tashima, M., et al. (2000) Suppression of heat shock protein-70 by ceramide in heat shock-induced HL-60 cell apoptosis. Journal of Biological Chemistry, 275, 8872-8879. doi:10.1074/jbc.275.12.8872

[14] Kondo, T., Matsuda, T., Kitano, T., et al. (2000) Role of c-jun expression increased by heat shock- and ceramide-activated caspase- 3 in HL-60 cell apoptosis. Possible involvement of ceramide in heat shock-induced apoptosis. Journal of Biological Chemistry, 275, 7668-7676. doi:10.1074/ibc. 275.11 .7668

[15] Chang, Y., Abe, A. and Shayman, J.A. (1995) Ceramide formation during heat shock: A potential mediator of alpha B-crystallin transcription. Proceedings of the $\mathrm{Na}$ tional Academy of Sciences of the United States of America, 92, 12275-12279. doi:10.1073/pnas.92.26.12275

[16] Jenkins, G.M., Cowart, L.A., Signorell P, J., et al. (2002) Acute activation of de novo sphingolipid biosynthesis upon heat shock causes an accumulation of ceramide and subsequent dephosphorylation of SR proteins. Journal of Biological Chemistry, 277, 42572-42578. doi:10.1074/jbc.M207346200

[17] Sawai, H. and Hannun, Y.A. (1999) Ceramide and sphingomyelinases in the regulation of stress responses. Chemistry and Physics of Lipids, 102, 141-147. doi:10.1016/S0009-3084(99)00082-1

[18] Komori, H., Ichikawa, S., Hirabayashi, Y. and Ito, M. (1999) Regulation of intracellular ceramide content in B16 melanoma cells. Biological implications of ceramide glycosylation. Journal of Biological Chemistry, 274, 89818987. doi:10.1074/jbc.274.13.8981

[19] Uchida, Y., Murata, S., Schmuth, M., et al. (2002) Glu- 
cosylceramide synthesis and synthase expression protect against ceramide-induced stress. Journal of Lipid Research, 43, 1293-1302.

[20] Niimura, Y. and Nagai, K. (2008) Metabolic responses of sulfatide and related glycolipids in madin-darby canine kidney (MDCK) cells under osmotic stresses. Comparative Biochemistry and Physiology: B, 149, 161-167.

[21] Niimura, Y., Moue, T., Takahashi, N. and Nagai, K. (2010) Medium osmolarity-dependent biosynthesis of renal cellular sulfoglycolipids is mediated by the MAPK signaling pathway. Biochimica et Biophysica Acta, 1801, 1155-1162.

[22] Niimura, Y., Moue, T., Takahashi, N. and Nagai, K. (2010) Modification of sphingoglycolipids and sulfolipids in kidney cell lines under heat stress: Activation of monohexosylceramide synthesis as a ceramide scavenger. Glycobiology, 20, 710-717. doi:10.1093/glycob/cwq018

[23] Muller, W.J., Naujokas, M.A. and Hassell, J.A. (1984) Isolation of large $\mathrm{T}$ antigen-producing mouse cell lines capable of supporting replication of polyomavirus-plasmid recombinants. Molecular and Cellular Biology, 4, 2406-2412.

[24] Niimura, Y. and Ishizuka, I. (2006) Isolation and identification of nine sulfated glycosphingolipids containing two unique sulfated gangliosides from the African green monkey kidney cells, Verots S3, and their possible metabolic pathways. Glycobiology, 16, 729-735. doi:10.1093/glycob/cwj114

[25] Tanaka, K., Yamada, M., Tamiya-Koizumi, K., et al. (2011) Systematic analyses of free ceramide species and ceramide species comprising neutral glycosphingolipids by MALDI-TOF MS with high-energy CID. Glycoconjugate Journal, 28, 67-87. doi:10.1007/s10719-011-9325-6

[26] Hanada, K. (2003) Serine palmitoyltransferase, a key enzyme of sphingolipid metabolism. Biochimica et Biophysica Acta, 1632, 16-30.

[27] Pewzner-Jung, Y., Ben-Dor, S. and Futerman, A.H. (2009) When do lasses (longevity assurance genes) become CerS (ceramide synthases)? Insights into the regulation of ceramide synthesis. Journal of Biological Chemistry, 281, 25001-25005. doi:10.1074/jbc.R600010200

[28] Venkataraman, K. Riebeling, C. Bodennec, J., et al. (2002) Upstream of growth and differentiation factor 1 (uog1), a mammalian homolog of the yeast longevity assurance gene 1 (LAG1), regulates N-stearoyl-sphinganine (C18(dihydro)ceramide) synthesis in a fumonisin B1-independent manner in mammalian cells. Journal of Biological Chemistry, 277, 35642-35649. doi:10.1074/jbc.M205211200

[29] Sridevi, P., Alexander, H., Laviad, E.L., et al. (2009) Ceramide synthase 1 is regulated by proteasomal mediated turnover. Biochimica et Biophysica Acta, 1793, 12181227. doi:10.1016/j.bbamcr.2009.04.006

[30] Laviad, E.L., Albee, L., Pankova-Kholmyansky, I., et al. (2008) Characterization of ceramide synthase 2: Tissue distribution, substrate specificity and inhibition by sphingosine-1-phosphate. Journal of Biological Chemistry, 283, 5677-5684. doi:10.1074/jbc.M707386200

[31] Mizutani, Y., Mitsutake, S., Tsuji, K. Kihara, A. and Igarashi, Y. (2009) Ceramide biosynthesis in keratinocyte and its role in skin function. Biochimie, 91, 784-790. doi:10.1016/j.biochi.2009.04.001
[32] Stiban, J., Tidhar, R. and Futerman, A.H. (2010) Ceramide synthases: Roles in cell physiology and signaling. Advances in Experimental Medicine and Biology, 688, 61-71. doi:10.1007/978-1-4419-6741-1 4

[33] Mizutani, Y., Kihara, A., Chiba, H., Tojo, H. and Igarashi, Y. (2008) 2-Hydroxy-ceramide synthesis by ceramide synthase family: Enzymatic basis for the preference of FA chain length. Journal of Lipid Research, 49, 23562364. doi:10.1194/jlr.M800158-JLR200

[34] Alderson, N.L., Rembiesa, B.M., Walla, M.D., et al. (2004) The human FA2H gene encodes a fatty acid 2hydroxylase. Journal of Biological Chemistry, 279, 4856248568. doi:10.1074/jbc.M406649200

[35] Niimura, Y. and Nagai, K. (2008) Modulation of fatty acid molecular species in sulfatide and its precursor galactosylceramide of Madin-Darby canine kidney (MDCK) cells under osmotic stresses. In: Sasaki, D., Ed. Glycolipids: New Research, Nova Science Publishers, Hauppauge, 18-28.

[36] Yabu, T., Imamura, S., Yamashita, M. and Okazaki, T. (2008) Identification of $\mathrm{Mg}^{2+}$-dependent neutral sphingomyelinase 1 as a mediator of heat stress-induced ceramide generation and apoptosis. Journal of Biological Chemistry, 283, 29971-29982. doi:10.1074/jbc.M805402200

[37] Clarke, C.J. and Hannun, Y.A. (2006) Neutral sphingomyelinases and nSMase2: bridging the gaps. Biochimica et Biophysica Acta, 1758, 1893-1901. doi:10.1016/j.bbamem.2006.06.025

[38] Wu, B.X., Clarke, C.J. and Hannun, Y.A. (2010) Mammalian neutral sphingomyelinases: Regulation and ro- les in cell signaling responses. Neuromolecular Medi- cine, 12, 320-330. doi:10.1007/s12017-010-8120-z

[39] Zumbansen, M. and Stoffel, W. (2002) Neutral sphingomyelinase 1 deficiency in the mouse causes no lipid storage disease. Molecular and Cellular Biology, 22, 36333638. doi:10.1128/MCB.22.11.3633-3638.2002

[40] Ito, H., Murakami, M., Furuhata, A., et al. (2009) Transcriptional regulation of neutral sphingomyelinase 2 gene expression of a human breast cancer cell line, MCF-7, induced by the anticancer drug, daunorubicin. Biochimica et Biophysica Acta, 1789, 681-690.

[41] Levy, M., Castillo, S.S. and Goldkorn, T. (2006) nSMase 2 activation and trafficking are modulated by oxidative stress to induce apoptosis. Biochemical and Biophysical Research Communications, 344, 900-905. doi:10.1016/j.bbrc.2006.04.013

[42] Levy, M., Khan, E., Careaga, M. and Goldkorn, T. (2009) Neutral sphingomyelinase 2 is activated by cigarette smoke to augment ceramide-induced apoptosis in lung cell death. Lung Cellular and Molecular Physiology, 297, L125-L133. doi:10.1152/ajplung.00031.2009

[43] Tafesse, F.G., Ternes, P. and Holthuis, J.C.M. (2006) The multigenic sphingomyelin synthase family. Journal of Biological Chemistry, 281, 29421-29425. doi:10.1074/jbc.R600021200

[44] Rani, C S., Abe, A., Chang, Y., et al. (1995) Cell cycle arrest induced by an inhibitor of glucosylceramide synthase. Correlation with cyclin-dependent kinases. Journal of Biological Chemistry, 270, 2859-2867.

[45] Shayman, J.A., Mahdiyoun, S., Deshmukh, G., et al. (1990) Glucosphingolipid dependence of hormonestimulated inositol trisphosphate formation. Journal of Bio- 
logical Chemistry, 265, 12135-12138.

[46] Ravid, T., Tsaba, A., Gee, P., et al. (2003) Ceramide accumulation precedes caspase-3 activation during apoptosis of A549 human lung adenocarcinoma cells. American Journal of Physiology. Lung Cellular and Molecular Physiology, 284, L1082-1092.

[47] Bleicher, R.J. and Cabot, M.C. (2002) Glucosylceramide synthase and apoptosis. Biochimica et Biophysica Acta, 1585, 172-178.

[48] Gouaze-Andersson, V. and Cabot, M.C. (2006) Glycosphingolipids and drug resistance. Biochimica et Biophysica Acta, 1758, 2096-2103.

doi:10.1016/j.bbamem.2006.08.012 